\title{
PRIBUMI SUBALTERN DALAM NOVEL LAMPUKI KARYA ARAFAT NUR (KAJIAN POSKOLONIAL GAYATRI C. SPIVAK)
}

\section{SUBALTERN NATIVE IN LAMPUKI NOVEL WRITTEN BY ARAFAT NUR (GAYATRI C. SPIVAK POSTCOLONIAL STUDY)}

\author{
Sulistianawati* \\ Alumni Program Pascasarjana Pendidikan Bahasa dan Sastra Indonesia-Daerah, \\ Universitas Negeri Surabaya, Indonesia \\ tianawatisulis@gmail.com \\ *penulis korespondensi
}

\begin{tabular}{l}
\hline Info Artikel \\
\hline Sejarah artikel: \\
Diterima: \\
3 April 2020 \\
Direvisi: \\
9 Juni 2020 \\
Disetujui: \\
11 Juli 2020 \\
\\
Kata kunci: \\
subaltern, poskolonial, \\
perlawanan, \\
pemberontak
\end{tabular}

\begin{abstract}
ABSTRAK
Pribumi subaltern menjadi subjek nyata adanya gejolak penindasan oleh serdadu pemerintah dan gerakan bawah tanah dalam situasi Aceh yang telah beralih menjadi Daerah Operasi Mililiter. Tujuan penelitian ini mendeskripsikan penyalahgunaan tahta tertinggi, adanya pemberontakan gerakan bawah tanah sebagai bentuk perlawanan, dampaknya bagi kaum subaltern seperti pelecehan seksual, mentalitas down, dan dimiskinkan. Data diperoleh dengan teknik pustaka dari sumber tertulis berupa kata dan kalimat dalam novel kemudian dianalisis dengan metode analisa deskriptif. Hasil penelitian menunjukan dominasi kekuasaan penguasa superior yang menduduki tahta tertinggi, dua bentuk perlawanan berupa caci maki serta aksi pemberontakan, dan dampaknya bagi subaltern begitu signifikan memunculkan keterpurukan, semakin merajalela pelecehan seksual, mentalitas down akhirnya termiskinkan. Pada akhirnya subaltern semakin lemah, ketakutan dan tak berdaya. Adanya persekutuan pemberontak sebagai akibat mentalitas era kolonial yang masih menjarah pemikiran masyarakat. Pada dasarnya penjajahlah yang menjadi cikal bakal adanya teroris dan pemberontakan. Penelitian ini diharapkan memberikan sumbangsih untuk mendukung kebijakan pemerintah mendisiplinkan politik agar tidak mengalami carut-marut. Serta menjadi pengingat bagi masyarakat akan masih adanya gerakan bawah tanah dalam bentuk apapun yang mengancam keberlangsungan hidup masyarakat lain, dalam menghadapi kolonialisme yang masih berkembang hingga saat ini.
\end{abstract}

\begin{tabular}{|c|c|}
\hline Article Info & ABSTRACT \\
\hline $\begin{array}{l}\text { Article history: } \\
\text { Received: } \\
3 \text { April } 2020 \\
\text { Revised: } \\
9 \text { June } 2020 \\
\text { Accepted: } \\
11 \text { July } 2020 \\
\text { Keyword: } \\
\text { subaltern, } \\
\text { postcolonial, resistance, } \\
\text { rebel }\end{array}$ & $\begin{array}{l}\text { Subaltern natives are the real subject of the turmoil of oppression by } \\
\text { government troops and underground movements in the Aceh situation which } \\
\text { has turned into the Military Operations Area. The purpose of this study is to } \\
\text { describe the abuse of the highest throne, the existence of an underground } \\
\text { movement rebellion as a form of resistance, the impact on the subalterns } \\
\text { such as sexual harassment, down mentality, and impoverished. Data } \\
\text { obtained by library techniques from written sources in the form of words } \\
\text { and sentences in the novel and then analyzed by descriptive analysis } \\
\text { method. The results showed the dominance of the power of superior rulers } \\
\text { who occupied the highest throne, two forms of resistance there are in the } \\
\text { form of insults and acts of rebellion, and the impact on subalterns was so } \\
\text { significant that it leds to adversity, increasingly rampant sexual harassment, } \\
\text { the down mentality finally impoverished. In the end the subaltern is getting } \\
\text { weaker, frightened and helpless. The existence of the rebel alliance is as a } \\
\text { result of the mentality of the colonial era which still plundered the minds of }\end{array}$ \\
\hline
\end{tabular}


the people. Basically, invaders are the embryo of terrorists and rebellion. This research is expected to contribute to support government policy to discipline politics. Therefore, it does not experience chaos. As well as a reminder to the public of the existence of underground movements in any form that threatens the survival of other communities, in the face of colonialism that is still developing today.

\section{PENDAHULUAN}

Salah satu kajian kritik sastra yang saat ini banyak dibicarakan dalam dunia akademisi adalah poskolonial. Poskolonial menawarkan pengungkapan konflik kehidupan manusia yang terjadi dimasa kolonial. Namun dalam ranah kajian sastra, poskolonial karyanya bukan hanya masa setelah kolonialisme berakhir tetapi karya yang ditulis sejak berlangsung hingga masa kini. Pada pemahaman poskolonial bahwa kolonialisme tidak pernah berakhir, melainkan tetap ada hingga sekarang dengan bentuk yang berbeda. Artinya poskolonial digunakan secara luas termasuk dalam kajian perlawanan pribumi dalam menghadapi penjajah luar maupun pemberontak negara sendiri.

Topik mengenai poskolonial terdapat dalam novel Lampuki karya Arafat Nur. Arafat Nur, seorang penulis produktif yang dalam karyanya yang menerima penghargaan DKJ 2010 berjudul Lampuki telah membeberkan permasalahan di Aceh, adanya gerakan bawah tanah atau pemberontak pada negaranya sendiri. Hal ini dipicu masyarakat yang masih terkungkung secara sikap, pola perilaku, pola kehidupan maupun perasaan akan adanya mentalitas pribumi yang kolonial, tentunya merupakan sejarah bangsa. Akibatnya pribumi sulit untuk melepaskan diri dari pengaruhnya, walaupun sudah memasuki era poskolonial. Era kolonial telah meninggalkan mentalitas penindas yang beringas dan pembudak dalam jiwa pribumi. Dalam jurnalnya Bahadur menuliskan bahwa oposisi biner yang ditinggalkan kolonial berdampak secara tidak langsung pada hegemoni antara pihal yang berkuasa dengan pihak yang dikuasai, antara pribumi dengan nonpribumi, antara perjuangan dan penindasan identitas.

Novel Lampuki yang jalur ceritanya merepresentasikan fenomena kehidupan masyarakat. Isinya yang menunjukan gejolak konflik dalam masyarakat yang terjadi antara tentara pemerintah dengan kaum gerilyawan yang berujung sensara oleh masyarakat kecil yang tidak berdosa. Aceh menjadi daerah kontroversi, sensitif dan rawan konflik yang setiap saat terror dendan sadar akan datang menghampiri. Novel, di dalamnya diungkapkan suatu konsentrasi kehidupan pada saat yang menegangkan, pemusatan pada kehidupan berbau ketegasan (Esten, 2013:8).

Gejolak konflik di Indonesia cikal bakalnya ada pada era kolonialisme, saat negara dijajah bangsa kolonial. Selama mengalami penjajahan tentu bangsa Indonesia mengalami kerugian. Secara pengelompokkan ras saja, kolonial Belanda memiliki andil besar dalam memposisikan rakyat Indonesia sebagai masyarakat kelas ketiga yang disebut inlander atau pribumi. 
Selain itu alasan Belanda melakukan pengelompokan atas dasar kepentingan ideologis dan politik. Berbagai hal yang dilakukan berakibat munculnya kelompok tertindas.

Pada sistem masyarakat sendiri terdapat tingkatan-tingkatan, lahir dari sini istilah kaum subaltern atau kaum kelas bawah berasal yang tertindas. Kaum subaltern memiliki berbagai cara untuk menyamai tingkatan atas. Cara untuk memperoleh pengakuan keberadaanya serta penghargaan oleh kelas atas ini menjadi objek poskolonial menurut Spivak. Perkembangan teori postkolonial dicetuskan kata subaltern ini menjadi sangat penting. Kelompok subaltern inilah yang mengalami penindasan dan tidak memiliki akses pada kelompok elit.

Pengagas teori subaltern ialah Antonio Gramsci, seorang pemikir poskolonial. Kemudian kajian ini dikembangkan oleh ahli lain yakni Gayatri C. Spivak melalui esainya yang berjudul can the subaltern speak mengatakan bahwa penjajahan tetap meningalkan bekas akan negara yang dijajah meskipun telah berakhir. Bekas penjajahan tersebut masih ada dalam berbagai bidang kehidupan, seperti bidang ekonomi, sosial, politik. Efek dari penjajahan yang telah berakhir tersebut memunculkan kelompokkelompok atau kelas-kelas bawah, terpinggirkan, termarginalisasi, ditekan, dan tidak memiliki akses untuk berbicara. Menurutnya era kolonial tetap menyisakan lelaki sebagai penguasa, mayoritas, dan perempuan adalah yang dikuasai (Spivak, 1993:83). Kaum subaltern dalam penelitian ini tak lain mayoritas lakilaki yang terintimidasi pihak tentara pemerintah serta para pemberontak kelas kakap.
Penelitian terkait tinjauan poskolonial dalam perspektif Gayatri C. Spivak masih dalam jumlah yang sedikit atau kurang dilakukan. Kurangnya penelitian yang relevan menjadikan penulis tertarik meneliti novel Lampuki menggunakan perspektif Gayatri menyoroti kaum subaltern. Berikut beberapa penelitian yang relevan, pertama dari jurnal Bahardur (2016) menggunakan tiga buah data berupa novel modern yakni novel Orang-orang Blanti karya Wisran Hadi, Maya karya Ayu Utami, dan Gadis Pantai karya Pramoedya Ananta Toer menunjukan bahwa pribumi terkhusus kaum perempuan menjadi bagian kelompok subaltern yang dimarginalisasi, dimiskinkan, mendapat pelabelan serta mendapati kekerasan seksual. Namun ada bentuk perlawanan dari perempuan subaltern dengan memupuk semangat diri, mengupgrade ilmu pengetahuan sebagai bentuk proteksi diri untuk mempertahankan nilai, tradisi budaya setempat.

Penelitian oleh Saputri (2019) mendalami novel karya Pramoedya yang tersohor dengan berbagai karyanya yang berlatar sejarah kolonial bangsa Indonesia. Hasil penelitian yaitu dominasi penjajahan terhadap subaltern berupa penindasan dan kekuasaan, dipegang Belanda sebagai superior. Dampaknya bagi pribumi berupa perubahan melemahnya mental menjadikan paranoid dan timbulnya rasa dendam. Perlawanan ditunjukan dengan anarkis lewat pemberontakan, pertempuran serta caci maki berlebih.

Selanjutnya penelitian yang dilakukan Nurfadilah (2019) berlatarbelakang era kolonial di jalan penjajahan jepang di Indonesia dalam novel Sang Maharani karya Agnes Jessica. Hasil penelitian menunjukan 
dominasi penjajahan dan pengaruh dominasi penjajahan dilakukan imbang. Sedangkan perlawanan dilakukan satu kali selangkah di depan dominasi penjajahan dan pengaruhnya. Ini membuktikan kaum subaltern terutama perempuan bersiasat lepas dari penjajahan. Kholifatu (2020) meneliti novel Arok Dedes dalam artikel ilmiahnya menunjukan adanya pengaruh tahta tertinggi oleh kasta Ksatria dan Brahmana, juga bentuk perlawanan kaum subaltern yang diprakarsai Arok Dedes terhadap Tunggul Ametung dengan cara menjadikan diri pada tingkatan tertinggi, atau kesetaraan kasta.

Berbeda dengan penelitian sebelumnya diatas, terkait permasalahan pribumi subaltern dan kolonialisme, penelitian ini difokuskan pada penyalahgunaan tahta tertinggi, adanya pemberontakan gerakan bawah tanah sebagai bentuk perlawanan, serta dampaknya bagi kaum subaltern dalam novel Lampuki. Alasan yang mendasari penelitian ini karena karya kaum subaltern dalam novel Lampuki karya Arafat Nur merupakan dokumen sejarah yang faktual, sejarah karya diciptakan beserta kondisi sesungguhnya, sehingga dapat memberikan sumbangsih gambaran fakta sejarah yang sebenarnya. Selain itu kaum penjajah dalam kolonialisme, pada pembahasan ini direpresentasikan kaum pemberontak yang berasal dari masyarakat pribumi yang terpengaruh adanya gerakan bawah tanah. Pada dasarnya penjajahlah yang menjadi cikal bakal adanya teroris dan pemberontakan. Hasil penelitian diharapkan dapat dijadikan landasan menyusun kebijakan pemertahanan daerah dari berbagai gerakan bawah tanah yang muncul serta mengancam keberlangsungan hidup masyarakat, dalam menghadapi kolonialisme yang masih berkembang hingga saat ini.

\section{METODE}

Penelitian ini termasuk jenis penelitian kualitatif, data yang digunakan berupa deskriptif. Data dalam metode kualitatif diuraikan menggunakan data verbal bukan angka yang temuan-temuannya tidak diperoleh melalui prosedur statistik atau bentuk hitungan lainnya (Corbin dkk, 2013:4-5). Kualitatif mengutamakan penafsiran akan bentuk verbal saja yaitu kata, frase, kalimat, klausa, dan wacana. Novel hasil buah pemikiran Arafat Nur ini merupakan sumber data yang diterbitkan oleh Gramedia, dengan tebal 344 halaman.

Data penelitian ini berupa teks yang terdiri dari sejumlah kata, kalimat dan paragraf dalam penceritaanya menggunakan sudut pandang orang ketiga (aku), yang kemudian dianalisis sesuai kebutuhan penelitian yaitu data yang berkaitan dengan perlawanan, penindasan pengaruh tahta tertinggi, serta perempuan termarginalisasi serta dilecehkan. Teknik pengumpulan data dengan teknik pustaka, dimana data yang didapat berupa bentuk verbal dibaca kemudian dipilah dan dicatat. Analisis data dilakukan dengan cara analisis isi novel, yang kemudian dibutuhkan adanya penafsiran akan tujuan dari penelitian ini. langkahlangkah analisis data dalam penelitian ini dilakukan peneliti untuk mengidentifikasi data yang akan dianalisis. Sebagaimana (1) adanya pengodean untuk memudahkan klasifikasi serta memastikan kevalidan data atau koherensi antara sumber data dengan penjabaran, (2) selanjutnya dianalisis dan diinterpretasikan menggunakan teori perspektif pascakolonial dan teori subaltern yang 
dikemukakan oleh Gayatri C. Spivak, (3) penarikan kesimpulan mengacu pada data yang telah dianalisis disimpulakan secara rinci dari hasil penelitian yang ditemukan peneliti.

\section{HASIL DAN PEMBAHASAN}

Peneliti menguraikan hasil penelitian dan pembahasan terhadap kajian subaltern pada novel Lampuki karya Arafat Nur dengan menggunakan teori poskolonial Gayatri C Spivak, yang terdiri dari tiga bagian. Pertama, penyajian hasil analisis data tentang penyalahgunaan tahta tertinggi. Kedua, adanya pemberontakan gerakan bawah tanah sebagai bentuk perlawanan. Ketiga, dampaknya bagi kaum subaltern dalam novel Lampuki.

\section{Penyalahgunaan Tahta Tertinggi dalam Novel Lampuki Karya Arafat Nur}

Penggambaran tokoh yang mewakili penyalahgunaan tahta tertinggi terhadap kaum subaltern dalam novel Lampuki, ditunjukan oleh tokoh tentara dan pemerintah tertinggi. Para tentara memanfaatkan stratanya atas pribumi, bertindak beringas tanpa ampun layaknya serdadu pembantai. Pada sisi lain pemerintahan Aceh kala itu, yang serakah akan jabatan dalam permainan poitik dan hanya membual janji belaka. Karena dalam hal ini, pemerintah yang seharusnya sebagai pelindung rakyatnya kini tak ubah sebagai macan yang menerkam anaknya sendiri. Hal tersebut terbukti dalam kutipan novel sebagai berikut.

\footnotetext{
Mengingat ketamakan pemerintah dan beringasnya serdadu-serdadu pembantai pada tahun-tahun itu, hati sekalian orang diranjai kebencian, murka dan dendam. (L:51)
}

\begin{abstract}
"Percayalah, kalau saya jadi presiden, tidak aka nada lagi darah orang Aceh yang tumpah setetes pun!" ujarnya ketika itu, yang menimbulkan rasa haru di hati kami semua, yang ucapan itu begitu saja kami percaya tanpa mengingat lagi masa lalu ayahnya. Tak beberapa lama setelah dia naik tahta, malah dia cepat-cepat mengirimkan ribuan prajurit pemburu kemari. Dia lupa dan tidak mau peduli lagi janjinya. (L: 326)
\end{abstract}

Hal ini sejalan dengan pemikiran Spivak bahwasanya kaum subaltern direpresentasikan sebagai kaum yang lemah dan tidak dapat menyuarakan aspirasinya atas kaum atas strata tinggi disini ialah para tentara dan pemerintah tertinggi. Tidak satupun pribumi membantah omongan maupun membalas perilaku para tentara yang keji, mereka hanya mampu mengumpat dalam hati bahkan mendendam atas perlakuan yang kurang berperikemanusiaan itu. Sedangkan para tentara hanya patuh pada pemerintah melaksanakan tugas tanpa berpedoman pada azasnya.

Pemerintah yang gelap mata mendewakan kedudukanya dalam ranah politik dan sosial hingga mengingkari janji. Lebih perihnya pemerintah saling menyikut, menyepak dan menerjang lawan politiknya tanpa mengihiraukan nasib rakyatnya. Negeri ini dapat hancur dan binasa oleh mereka pemangku kekuasaan superior yang tidak amanah, tidak bertanggung jawab, justru menghadirkan maut bagi rakyat sekalian. Ini menjadi salah satu bukti strata tinggi baik aparatur, penguasa daerah maupun negara untuk melimpahkan hasil permainan busuk 
mereka pada rakyat lemah. Melalui kutipan berikut juga terkait penyalahgunaan tahta oleh pemerintah Aceh yang justru menyengsarakan kaum subaltern, atau dapat dikatakan menjajah rakyat sendiri dengan upaya korupsi.

Begitulah, berbilang tahun kejayaan bumi Pasai terus dikeruk tanpa henti. Semua hasilnya habis digunakan untuk kepentingan pembangunan pusat pemerintahan, dan sebagian lagi digelapkan komplotan pejabat tengik, yang kemudian mereka menjadi kaya raya ditengah penduduk yang terjangkit busung lapar. Sejumlah pemimpin ternyata diam-diam menjajah kaum sendiri. (L: 47)

Sama halnya dengan kedua kutipan di atas terkait dengan dunia politik yang berbau koruptor. Pemerintah yang semakin merajalela mengeruk kekayaan negara, tanpa sedikitpun memberikanya pada rakyat. Hal ini semakin menegaskan penguasa telah merampas hak dari pihak terjajah yakni kaum subaltern. Hak yang dimaksud disini sesuai dengan kalimat yang bergaris miring "busung lapar" yakni hak memperoleh jaminan kesehatan dan juga sembako. Namun realitanya pemerintah semakin kaya, rakyat semakin dimiskinkan.

\section{Pemberontakan Sebagai Bentuk Perlawanan dalam Novel Lampuki Karya Arafat Nur}

Dalam penelitian ini, pemberontakan sebagai bentuk upaya perlawanan digambarkan dalam bentuk caci maki dan persekongkolan pemberontak. Bentuk perlawanan yang sangat menyimpang tersebut dijelaskan dalam penyajian dan pembahasan hasil analisis data berikut.

\section{Perlawanan oleh Gerakan Bawah Tanah dalam Bentuk Caci Maki}

Perlawanan dengan cara memberontak hanya dilakukan beberapa pribumi yang tergabung dalam gerakan bawah tanah laskar Peurincun dengan lawan mainnya para serdadu pemerintah. Sedangkan sisanya menjadi rakyat golongan subaltern. Dalam hal ini pemberontak melakukan penjajahan pada negaranya sendiri yang dipicu emosionalitas, pembalasan dendam, dan keinginan memerdekakan Lampuki dan sekitarnya dari para serdadu pemerintahan serta Parpol yang bergerak di belakangnya.

Dalam penelitian ini, perlawanan dan kekuasaan yang dimiliki kaum subaltern digambarkan dalam bentuk caci maki dan persekongkolan saja. Mereka hanya sebagian kecil pemuda yang tergerak mengikuti jejak sesat sebagai pemberontak atas tanah kelahiranya sendiri. Mayoritas kecil yang tergabung melakukan perlawanan, sisanya hanya manut ngalor ngidul dalam bahasa Jawa yang berarti ikut alur, pada tentara penjaga pos. Perlu ditegaskan, caci maki yang dilontarkan bukan dari seluruh kaum subaltern, namun yang dulunya subaltern kemudian membentuk gerakan pemberontak ialah Ahmadi dkk, sebagai berikut.

Di jalan lingkungan perumahan, sambil berhilir mundar-mandir, dia meludah dan menyerapah, "penjajah! Anjing! Anjing penjajah! Terkutuklah kalian, penjajah Laknat!'”. (L:57) 
Mereka semakin menebar kecurigaan, menuding, menuduh, mengecam, mengancam, mencecar, dan memaki-maki serupa kelakuan Ahmadi kala berang, dan akhirnya mereka menyatakan bahwa kampung ini menyembunyikan musuh negara. (L: 220-221)

Salah satu tokoh yang menyuarakan aksi perlawanan dalam bentuk cacian maupun perbuatan ialah Ahmadi, si kumis tebal bersama anggota laskar Peurincun lainnya. Ahmadi (L:57) menyerapahi para serdadu pemerintah atas kekuasaan mereka yang superior. Kata-kata yang dimiringkan dilontarkan untuk orang yang bersalah dan orang yang memberikan dendam pada mereka. Sedangkan kalimat pada (L:220) menyiratkan tentara yang berkeinginan kuat memusnahkan gerakan bawah tanah atau pemberontak yang tidak pantas menduduki tanah negara ini. Dalam hal ini yang dikatakan caci maki yang dialami para gerilya merupakan bentuk semangat yang membara untuk memulai siasat perlawanan atas kekuasaan serdadu yang superior.

\section{Perlawanan yang Dilakukan dalam Bentuk Persekongkolan}

Pemikiran strukturalis mengenai pemberontakan, sempat menimbulkan spekulasi pendapat para pemikir kajian subaltern. Spivak mengemukakan kaum subaltern juga dapat melakukan aksi pemberontakan guna melawan dominasi penjajah. Namun dibutuhkan keberadaan kaum elit yang menjembatani perjuangan kelompok tersebut. Novel Lampuki menceritakan bagaimana rakyat subaltern dikuasai, ditindas, disiksa fisik hingga batinya yang hanya terpaku pasrah pada keadaan. Namun beberapa bentuk pemberontakan hingga perlawanan yang dilakukan oleh kaum lelaki maupun perempuan yang bersekongkol. Para lelaki dan anak muda subaltern yang ditindas oleh anak buah pemerintahannya sendiri (para serdadu) memberikan perlawanan. Perlawanan yang dilakukan berupa bergabung dalam laskar Peurincun atau pemberontak, dapat dijelaskan dalam kutipan berikut.

Para anak yang membuat perlawanan itu disulut oleh rasa sakit hati terhadap kekejian yang pernah berlangsung disini, dan mereka tak sanggup tahan menyaksikan orang-orang bersenjata itu datang kemari untuk berlagak-lagak, mencacah dan menista kami. (L:62)

Mereka meledakkan bom rakitan disana-sini, yang tidak menimbulkan korban jiwa selain sekedar merusak pos jaga dan kantor polisi, gedung-gedung perkantoran pemerintah, sekolah dan sejumlah bangunan lain sebagai peringatan bagi kaki-kaki tangan musuh tuhan. (L:249)

Pada kutipan (L:62) diatas menjelaskan bahwa hal-hal yang dilakukan oleh kaum terjajah menghadapi penjajah dari negerinya sendiri memiliki cara tersendiri. Dalam kutipan tersebut para anak yang masih remaja subaltern melakukan perlawanan sendiri terhadap penjajahan utusan pemerintah yang diatasnamakan politik itu dengan kegiatan frontal dan keji. Hal ini tentu dipicu rasa sakit hati remaja yang menyaksikan orang tuanya teraniaya oleh serdadu dengan pashrahnya. Pemberontakan satu- 
satunya cara yang terbesit dibenak remaja desa itu. Para remaja mengikuti latihan dengan para pemberontak sebelum melancarkan aksinya.

Kemudian kutipan

merupakan hasil realisasi didikan para anggota laskar pemberontak. Mereka tentu tidak hanya diajari merakit bom, juga menggunakan senjata, pelatihan fisik dan kelincahan melarikan diri secepat kilat. Hal ini tak lain menjadikan mereka menjadi pemberontak sesungguhnya, setelah berhasil merusak sarana publik yang dibangun pemerintah untuk menunjang kinerja tokoh publik tersebut. Serta menyingkrikan para serdadu yang dianggap menjajah daerah mereka. Perseturuan ini tak berujung, bahkan ada perempuan yang diam-diam melancarkan aksi pemberontakan itu dengan cara menagih pajak pada penduduk kampong atas dan perumahan. Hasil itu diberikan pada suaminya Ahmadi selaku pimpinan laskar, digunakan membeli bahan bom rakitan dan senjata. Sebagaimana ditunjukan pada kutipan berikut.

Tiada mungkin pemberontak seberani itu menghampiri kawanan prajurit yang bersenjata lengkap, apalagi dengan penampilan tiada menyakinkan semacam itu, terlebih lagi dia itu perempuan lemah, meskipun dia punya senjata, sungguh tak mungkin sanggup melawan belasan tentara bertubuh besar serta kuat-kuat pula (L:110)

Pada kutipan diatas menjelaskan adanya kaki tangan pemberontak yang tak lain digambarkan oleh tokoh Halimah, istri Ahmadi. Halimah dengan wajah polos namun cerdik berhasil mengelabuhi para serdadu pemerintah. Bagi para tentara itu, tidaklah pemberontak berani menampakan diri, bahkan dalam wujud perempuan desa yang lemah. Novel Lampuki menceritakan Halimah sebagai penguntit pajak di kampong maupun perumahan, yang hasilnya diberikan suaminya untuk menyokong kejayaan laskar pemberontak dan kehidupan keseharian saat ditinggal suaminya di hutan. Hal ini mengambarkan Halimah sebagai kaum subaltern yang berusaha mengelabuhi para tentara untuk mempertahankan diri serta melayangkan aksinya tanpa sedkitpun dicurigai bersekongkol dengan pemberontak dengan kemahiran serta kelicikannya. Sesuatu yang dilakukan Halimah sebagai bentuk perlawanan subaltern untuk bertahan hidup melawan permainan politik pemerintah dengan keberadaan serdadu kiriman, yang diangap sebagai penjajah. Padahal Halimahlah sekongkolan penjajah yang sesat memperkeruh keadaan kampong dengan aksi nekad gerombolan pemberontak.

\section{Dampak Penjajahan bagi Kaum Subaltern}

Berdasarkan temuan data penelitian diatas, mengenai permasalahan tahta tertinggi dan upaya perlawanan yang menyimpang dilakukan kelompok laskar. Berikut penindasan yang dialami kaum pribumi sebagai kelompok subaltern sesunggunya terwujud dalam hal-hal berikut.

\section{Pelecehan Seksual}

Pengaruh dominasi para serdadu yang beringas menindas kaum subaltern khususnya perempuan dari segi fisik ialah dengan dilecehkan tubuhnya. Seperti pendapat Nurfadilah 
(2019:10) pengaruh dominasi penjajah terhadap subaltern dari segi fisik merupakan dampak yang diterima oleh para jugun ianfu (budak seks) berupa penyiksaan dan kuasa dari para penjajah. Bahkan dalam kelemahan hanya bisa pasrah yang tak kuasa menanggung perlakuan penjajah.

Perempuan yang mendapati kekerasan termasuk dalam tindak pemerkosaan dan pelecehan seksual. Terkait dengan pernyataan tersebut perempuan Lampuki yang mengalami pelecehan secara seksual oleh serdadu pemerintah yang bertugas disana. Tubuh pribumi perempuan ini tak berdaya dan dijadikan objek pelecehan para serdadu yang bertugas dan lama tidak bersua dengan istrinya. Hingga tega dan terang-terangan melakukan hubungan seksual secara massal dan bergantian. Mereka melampiaskan hasrah birahi yang mengebu-gebu bak binatang buas itu yang tanpa ampun menyerbu santapannya. Inilah dampak penjajahan yang merugikan kaum perempuan subaltern, ditunjukan melalui kutipan berikut.

Para prajurit melucuti pakaianya sampai tidak sehelai benang pun melekat di tubuh perempuan yang menggairahkan kehausan birahi mereka. Tubuh bugil itu diseret ke sebuah tempat, dan orang perkasa itu mengangkanginya secara bergantian, secara biadab. Setelah puas, belum jua berakhir pula azab atasnya. Di dekat sebuah alat listrik, tubuh lemah itu disandarkan ke dinding, dengan amat kejinya salah seorang menyetrum selangkangnya, sampai perempuan itu pingsan berkalikali dan akhirnya mati kelelahan setelah tubuhnya tidak sanggup lagi menahan dera siksaan. (L:23).

Tindakan para penguasa dalam kutipan diatas merupakan bentuk kekerasan terang-terangan menjadikan perempuan budak seks mereka. Perempuan diposisikan sebagai pihak yang dikuasai sehingga tidak dapat menolak. Perempuan desa ini selain mengalami pelecehan seksual juga tindak pemerkosaan berujung meregangnya nyawa. Dalam kasus perkosaan secara terang-terangan yang dialami oleh perempuan desa tersebut tergambar bahwa perempuan desa adalah pihak inferior yang hanya memiliki kemenarikan dari segi seks, hanya berfungsi sebagai objek seks, tidak memiliki kekuatan bertahan dari seks, dan pantas diperlakukan dengan tidak wajar. Sebagai kelompok masyarakat pribumi yang dijadikan subaltern dan tertindas di negerinya sendiri, oleh penjajah negerinya sendiri. Hal ini sungguh miris dirasakan pada era kolonial dengan objek perempuan lemah.

\section{Mentalitas Down}

Pengaruh dominasi penguasa terhadap subaltern dari segi mental mengakibatkan seseorang ada dalam keadaan lemah dan pasrah atas kekuasaan. Mental disini ialah batin yang diserang hingga menjadikan pribumi kurang memiliki semangat hidup. Pribumi ini hanya dalam keseharian yang membosankan, tersiksa dan menyendiri. Bahkan ketakutan akan ancaman sering menyelimuti hari-hari mereka. Sebagaimana ditunjukan kutipan berikut.

Rasa gemetar tidak kunjung hilang sekalipun tiada muncul 
peristiwa besar di samping jalan raya. Bahkan, mereka yang berdiam diri di rumah pun merasakan ketakutan. (L:170)

Serdadu menganggap orang yang memiliki kumis paling tebal itu tidak bisa dibiarkan hidup lebih lama lagi. (L:230)

Berdasarkan kutipan diatas para pribumi terjajah dalam keadaan tidak berdaya (L:170). Setelah peristiwa pemberontakan itu, pribumi subaltern dituding sebagai komplotannya, hingga mereka tidak berani keluar rumah. Mereka merasakan takut menjadi bulan-bulanan serdadu pemerintahan itu. Ketakutan para pribumi terjajah tidak lagi memiliki semangat hidup. Tiap hari berdiam diri dan terpuruk batinnya. Mereka yang dahulunya beraktifitas seperti biasa tiba-tiba terhenti layaknya negara terguncang wabah virus pandemic hingga adanya lock down area. Miris sekali tidak ada dari subaltern memberikan perlawanan hanya pasrah pada keadaan.

Begitu pula kutipan (L:230) memperlihatkan bahwa kaum penguasa membawa pengaruh mental down kaum terjajah, semangat yang dulu dimiliki pribumi, tidak lagi dimiliki sekarang. Hal ini akibat para serdadu yang mencurigai setiap pribumi lelaki yang berkeliaran dan memiliki kumis tebal. Ketidakberdayaan ini membuat para lelaki mencukur kumis mereka hingga klimis tanpa sehelai pun, demi agar tidak dicurigai yang berujung pembunuhan keji. Dominasi penguasaan ini menjadikan para subaltern yang mengikuti jejak pemberontak semakin kuat. Hal ini dipucu rasa dendam akan penguasaan yang semakin superior.

\section{Dimiskinkan}

Pribumi subaltern mengalami pemiskinan ekonomi karena tindakan para serdadu pemerintah yang terus mengebu-gebu mencurigai pribumi menyembunyikan pemberontak musuh negara. Banyak dari harta benda mereka yang dibanting hingga rusak secara paksa dengan mendobrak setiap pintu rumah. Tidak cukup disitu terjadinya baku hantam yang mengakibatkan kerugian material yang cukup banyak. Gedung-gedung sebagai sasaran amukan pertempuran pemberontak dengan para serdadu. Tidak cukup hanya dua diatas, para subaltern menjadi korban kelaparan, kebersihan dan kecemasan. Akibat pelarian demi menghindarkan diri dari amukan massal serdadu. Sebagaimana ditunjukkan melalui kutipan berikut.

Aku mendengar di beberapa tempat sudah sudah meletus perang terbuka, pembakaran rumah-rumah, sekolah-sekolah, gedung perkantoran sekolah, dan bangunan apa saja yang berpeluang untuk bisa dibakar, serta begitu banyak penduduk yang jatuh korban setiap harinya. (L: 204)

Aku tidak bisa membantah ataupun bertindak manakala mereka mengobrak-abrik seisi rumah, memecahkan pinggan hadiah perkawinan yang merupakab barang-barang paling berharga yang ada pada kami. (L: 293)

Pelarian yang tak terduga ini ternyata sampai sepekan, dalam keadaan tubuh kami yang lelah, kotor dan bau, tanpa ada bekal yang kami bawa selain 
kecemasan dan kemarahan (L: 314).

Berdasarkan kutipan (L:204) tersebut tokoh aku mewakili kaum subaltern yang mengalami kerugian besar. Selain kerugian fasilitas umum, juga nyawa penduduknya. Para subaltern hanya bisa berada di belakang layar sambil meratapi nasib atas adu nyali pemberontak dengan aparatur. Selanjutnya (L:293) menunjukan kerugian ekonomi yang diakibatkan kemarahan serdadu yang memeriksa setiap sudut rumah penduduk tanpa memandang kedudukannya di masyarakat. Tokoh aku ialah tokoh sentral berprofesi sebagai teungku (pemuka agama). Namun tidak ada dari para serdadu yang menghormatinya. Kemudian pada kutipan (L:314) para subaltern lelaki melarikan diri, hingga keadaan lebih tenang. Kerugian yang ditimbulkan dirasakan para istri dan anak yang ditinggal di rumah, saat melakukan misi pelarian semantara itu. Ironinnya bukan perempuan yang banyak mengalami pemiskinan secara ekonomi, tetapi kaum lelaki subaltern. Mereka yang tidak memiliki kemampuan untuk bersuara. Tentulah novel ini cocok dikaji poskolonial, pemiskinan yang dirasakan pribumi lain akibat persekongkolan pribumi nakal dalam bentuk pemberontaka merupakan ciri ideology kolonialis. Hal yang dilakukan secara terselubung oleh tokoh Ahmadi dengan bergerak santai dan diam-diam melancarkan sejuta aksi pengeboman pos jaga. Tanpa perlu diberikan label identitas diri pribumi subaltern, mengalami penindasan secara terang-terangan dan halus. Perseteruan kedua kubu yang saling menjudge lawanya ialah penjajah negeri sendiri. Sesungguhnya misi yang dilayangkan laskar Peurincun ialah merugikan dimata rakyat dan negara. Sedangkan yang dilakukan serdadu pemerintah ialah mengamankan daerah demi menunaikan tugas aparatur negara. Hanya saja disisipi tindak amoral dan semena-mena yang menjadikan subaltern berasa dijajah. Kultur yang ada tidak memberikan kesempatan untuk memakmurkan diri secara ekonomi.

\section{PENUTUP}

Kaum pribumi subaltern dalam novel Lampuki, banyak mengalami penindasan dan menjadi golongan subaltern di negerinya sendiri. Hal ini diakibatkan perilaku pribumi yang bermental penjajah. Juga para serdadu pemerintahan yang diktator. Selain faktor tersebut, pemerintah kala itu cukup otoritarianisme, dengan adanya sistem politik yang menyimpang. Pemerintah yang seharusnya sebagai pelindung rakyatnya tak ubah sebagai macan yang menerkam anaknya sendiri.

Dari hasil penelitian terhadap permasalahan tersebut dalam novel Lampuki dengan kajian poskolonial, oleh Gayatri C Spivak tentang kaum pribumi subaltern menunjukan adanya penyalahgunaan tahta tertinggi. Tahta tertinggi dipegang oleh pemerintah mencakup parpol dan para serdadu penjaga pos Peurincun dan sekitarnya. Negeri ini dapat hancur dan binasa oleh mereka penguasa superior yang tidak amanah dan tidak bertanggung jawab.

Perlawanan dalam bentuk pemberontakan disini, hanya dilakukan beberapa orang saja yang tergabung dalam laskar Peurincun bukan seluruhnya subaltern pribumi Lampuki. Dua bentuk perlawanan dengan caci maki serta pemberontakan pada para serdadu pemerintah, yang dikirim pemerintah tertinggi. Bagi anggota 
laskar pemberontak, bencana akan menjadikan serdadu jera dan lekas meninggalkan pos jaga. Ironinya, akibat tindak pemberontakan yang dilancarkan Ahmadi dkk, subaltern lain semakin ditindas, disiksa, diatur dan dikuasai para serdadu pemerintah.

Dua cara perlawanan tersebut justru hanya memperkeruh suasana hingga membuat subaltern lebih lemah, ketakukan dan merugi. Hal ini memberikan dampak signifikan memunculkan keterpurukan subaltern hingga semakin merajalela pelecehan seksual, menjadikan mentalitas down dan subaltern akhirnya semakin dimiskinkan. Timbulah sebuah inisiatif subaltern untuk mengakhiri bencana tak berujung ini, sebagai jalan pintas satu-satunya ialah bersembunyi di hutan. Dengan tujuan mengakhiri bersitegang kedua kubu serdadu yang berlagak penguasa yang menindas, menghardik dan para pemberontak sesungguhnya atau mereka golongan subaltern yang melakukan perlawanan dengan frontal.

$$
\text { Selanjutnya diharapkan }
$$

penelitian ini dapat memberikan sumbangsih untuk mendukung kebijakan pemerintah mendisiplinkan politik agar tidak mengalami carutmarut. Serta menjadi pengingat bagi masyarakat akan masih adanya gerakan bawah tanah dalam bentuk apapun yang mengancam keberlangsungan hidup masyarakat lain, dalam menghadapi kolonialisme yang masih berkembang hingga saat ini.

\section{DAFTAR PUSTAKA}

Bahardur. (2016). Pribumi Subaltern dalam Novel-novel Indonesia Pacakolonial.

Gramatika,3.i(1),89-100.

https://doi.org/dx.doi.org/10.2 2202/JG.2017.V3i1.1876
Corbin \& Strauss. (2013). Dasar-Dasar

Penelitian Kualitatif

Tatalangkah dan Teknik-

Teknik Teoritisasi Data. Terj.

Muhammad Shodiq dan Imam

Muttaqien. Yogjakarta:

Pustaka Pelajar.

Esten, Mursal. (2013). Kesusastraan; Pengantar Teori dan Sejarah. Bandung: Angkasa.

Foulcher dan Day. (2006). Clearing A Space, Kritik Poskolonial tentang Sastra Indonesia Modern. Terjemahan Bernard Hidayat. Jakarta: Yayasan Obor Indonesia.

Hamzah, Azhar. (2017). Dominasi Penjajah Terhadap Subaltern dalam Novel Jugun Ianfu: Jangan Panggil Aku Miyako karya E. Rokajat Asura (Suatu Tinjauan Poskolonial Gayatri C. Spivak). Skripsi: Universitas Negeri Makassar.

Kholifatu \& Tjahjono. (2020). Subaltern dalam Novel Arok Dedes Karya Pramoedya Ananta Toer: Kajian Poskolonial Gayatri Spivak. Stilistika, Vol 13(1), (120126) https://doi.org/: http://dx.doi.org/10.30651/st. v13i1.3656.

Nur, Arafat. (2019). Lampuki. Jakarta: Gramedia Pustaka Utama

Nurfadilah. (2019). Dominasi Penjajahan Terhadap Subaltern dalam Novel Sang Maharani Karya Agnes Jessica: Suatu Tinjauan Poskolonial Gayatri C. Spivak. Skripsi: Universitas Negeri Makasar. 
Saputri, Nur. Fauziah. (2019). Dominasi Penjajah Terhadap Subaltern Dalam Novel Larasati Karya Pramoedya Ananta Toer (Suatu Pendekatan Poskolonial Gayatri C. Spivak ). eprints http://eprints.unm.ac.id/1398/

Soraya, (2015). The Subaltern Voice In A Thousand Splended Suns. Artikel I lmiah. Jurnal Lingua Cultura Vol 9 No.2 tahun 2015.

journal.binus.ac.id/index.php/ lingua.

Strauss, Anselm dan Corbin, Juliet. (2013). Dasar-Dasar Penelitian Kualitatif Tatalangkah dan TeknikTeknik Teoritisasi Data. Terj. Muhammad Shodiq dan Imam Muttaqien. Yogyakarta: Pustaka Pelajar.

Upstone, Sara. (2009). Spatial Politics in the Postcolonial Novel. England: Ashgate Publishing Limited 